\title{
Penentuan Waktu Panen untuk Produksi Benih Bermutu Tanaman Kacang Panjang (Vigna sinensis L.)
}

\section{IDA AYU MAYUN*), A.A. MADE ASTININGSIH, I WAYAN SEDANA, DAN I GUSTI NGURAH RAKA}

\author{
Program Studi Agroekoteknologi Fakultas Pertanian Universitas Udayana \\ J1. PB. Sudirman Denpasar Bali 80232 \\ ${ }^{*}$ E-mail: idaayumayun@unud.ac.id
}

\begin{abstract}
Determination of Harvest Time for Quality Seed Production of Long Bean Plants (Vigna sinensis L.). Seed maturity generally occurs at the same time as fruit maturity. When the fruit reaches its physiological level, it is the best time to get seeds with high quantity and best quality. Early harvest before physiological maturity many seeds have not been completely filled so that they will produce low quality seeds because many seeds are wrinkled. Meanwhile, when harvested after physiological maturity, the seeds experience weather conditions so that many seeds experience physical and physiological quality deterioration. The research aimed to get the right harvest time in the production of quality seeds of long bean plants. This study used a randomized block design with 6 treatments at harvest pods after blooming and 4 replications. The six treatments were harvest age 14, 17, $20,23,26$, and 29 days after the flowers bloom. The results showed that the right time to harvest pods for the production of long bean seeds was 26 days after blooming, the color of the pods has changed from green to yellow, the seeds have the highest dry weight $(7,56 \mathrm{~g})$, the best germination capacity $(100 \%)$, and maximum vigor $(88,78 \%)$.
\end{abstract}

Keywords: harvest time, long beans, seed quality

\section{PENDAHULUAN}

Ketersediaan benih dengan jumlah dan mutu yang memadai sangat diperlukan untuk meningkatkan hasil sayur polong dalam budidaya tanaman kacang panjang. Mutu benih tanaman kacang panjang salah satunya dipengaruhi oleh ketepatan waktu panen polong untuk benih. Panen calon benih merupakan salah satu kegiatan penting dalam rangkaian proses produksi benih bermutu. Pemasakan benih merupakan rangkaian perubahan fisik, fisiologis, dan morfologis yang terjadi pada bakal buah dan bakal biji sejak pembuahan sampai buah dan biji mencapai masak fisiologis. Tahapan proses pemasakan buah 


\section{IDA AYU MAYUN et al. Penentuan Waktu Panen untuk Produksi Benih...}

dan biji akan dicirikan secara spesifik oleh penampilan indikator-indikator fisik, fisiologis, dan morfologis, yang dapat dicatat sebagai penanda tingkat kemasakan benih.

Kemasakan benih umumnya terjadi bersamaan waktunya dengan kemasakan buah. Saat masak fisiologis merupakan waktu panen yang tepat untuk mendapatkan benih dengan kuantitas tinggi dan mutu terbaik. Panen dini sebelum masak fisiologis banyak benih belum terbentuk dan terisi secara sempurna sehingga akan menghasilkan benih dengan mutu rendah karena banyak benih yang keriput. Sedangkan panen pasca masak fisiologis akan terjadi deraan cuaca lapang terhadap benih sehingga banyak benih mengalami kemunduran mutu sebelum panen.

Periode pemasakan benih dimulai sejak selesainya proses pembuahan sampai panen dan umumnya kemasakan benih bersamaan waktunya dengan kemasakan buah (Vera Cruz et al., 2018). Pada tingkat kemasakan tersebut benih diduga telah masak fisiologis sehingga benih memiliki cadangan makanan sempurna untuk mendukung pertumebuhan kecambah sehingga didapat daya perkecambahan maksimum. Menurut Sanoto et al. (2017), benih yang telah masak fisiologis mempunyai cadangan makanan sempurna sehingga dapat menunjang pertumbuhan kecambah.

Ciri-ciri visual kemasakan fisiologis telah digunakan sebagai indikator dari kematangan benih secara fisiologis untuk beberapa jenis tanaman. Hilangnya warna hijau pada polong tanaman okra disarankan sebagai indikator kematangan fisiologis benih (Santos et al., 2020). Beberapa kriteria lain yang juga dipakai sebagai indikator yang mudah diidentifikasi untuk mengkarakterisasi kematangan benih, seperti terbentuknya lapisan hitam (black layer) pada jagung (Nleya \& Kleinjan, 2019); kadar air pada benih gandum (Calderini et al., 2000). Hasil penelitian tentang ciri-ciri visual kemasakan fisiologis untuk panen benih tanaman kacang panjang belum dijumpai, sehingga penelitian untuk hal itu sangat penting dilakukan.

Penelitian ini bertujuan untuk menentukan ciri-ciri masak fisiologis polong tanaman kacang panjang sebagai pedoman penentuan waktu yang tepat untuk panen polong dalam rangka produksi benih bermutu.

\section{BAHAN DAN METODE}

Penelitian ini dilaksanakan di Subak Balangan, Desa Kuwum, Kecamatan 
Mengwi, Kabupaten Badung. Penelitian dilaksanakan bulan Juni - September 2019.

Bahan-bahan yang digunakan adalah benih kacang panjang, pupuk (urea, TSP, KCL), pupuk kandang, kampil, dan kertas CD. Alat yang digunakan terdiri atas gunting, timbangan digital, alat tulismenulis, dan kamera.

Penelitian ini menggunakan rancangan acak kelompok (RAK) sederhana satu faktor, dengan umur panen polong sebagai perlakuan. Umur panen polong dihitung dalam hari sejak bunga mekar (hsbm), dan dalam penelitian ini sebanyak 6 umur panen polong dipakai sebagai perlakuan. Keenam umur panen polong tersebut, yaitu umur 14 hsbm, 17 hsbm, 20 hsbm, 23 hsbm, 26 hsbm, dan 29 hsbm. Perlakuan diulang sebanyak 4 kali sehingga diperoleh sebanyak 24 unit percobaan.

Tanah diolah sampai gembur dan dibuat guludan dengan panjang 2,5 m, lebar $1 \mathrm{~m}$, dan tinggi $25 \mathrm{~cm}$. Pemupukan dengan pupuk kandang dosis 20 ton/ha saat pengolahan tanah, pupuk urea TSP dan KCL diberikan pada saat tanam berturutturut dengan dosis $100 \mathrm{~kg} / \mathrm{ha}, 50 \mathrm{~kg} / \mathrm{ha}$, dan $50 \mathrm{~kg} / \mathrm{ha}$. Jarak tanam benih kacang panjang $50 \mathrm{~cm}$ x $50 \mathrm{~cm}$ dengan 2 benih per lubang, dan ajir setinggi 1,5 m. Pemeliharaan tanaman meliputi pengairan, pengendalian gulma, pengendalian hama dan penyakit.

Panen polong kacang panjang dilakukan sesuai dengan perlakuan dan panen dilakukan pada tanaman sampel. Sampel tanaman untuk panen polong ditetntukan sebanyak 5 tanaman pada masing-masing petak percobaan.

Perkembangan karakter selama pertumbuhan dan perkembangan polong ditetapkan menjadi indikator. Indikator tersebut meliputi indikator fisik (perubahan kadar air benih, keragaan benih, berat segar benih, dan berat kering benih), indikator fisiologis (viabilitas dan vigor benih), dan indikator morfologis (perubahan warna polong dan warna benih). Indikatorindikator tersebut diamati dari populasi tanaman yang diambil secara acak di lapangan, setiap indikator diwakili oleh 5 tanaman dan masing-masing indikator diulang sebanyak 3 kali. Pengamatan indikator-indikator tersebut dilakukan setiap 3 hari sejak umur polong 1 minggu setelah bunga mekar sampai polong kering di pohon. Indikator morfologi diselaraskan dengan indikator fisik dan indikator fisiologis untuk mendapatkan kriteria/indikator panen secara visual yang bisa diterapkan secara praktis di lapangan. 


\section{IDA AYU MAYUN et al. Penentuan Waktu Panen untuk Produksi Benih...}

Variabel yang diamati meliputi:

1) Indikator fisik

a. Kadar air benih, diukur setiap panen menggunakan metode oven. Sebanyak 100 butir benih ditimbang berat segarnya kemudian dioven pada suhu $80^{\circ} \mathrm{C}$ sampai mencapai berat kering konstan dan dicatat beratnya. Pengukuran diulang 3 (tiga) kali. Kadar air benih dihitung dengan rumus sebagai berikut.

$$
\text { Berat segar }(\mathrm{g}) \text { - Berat kering oven }(\mathrm{g})
$$

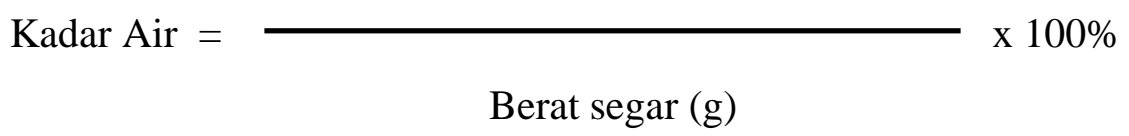

Berat segar $(g)$

b. Perkembangan berat kering benih, diamati setiap panen benih sama seperti pada pengukuran kadar air benih tetapi hanya dicatat berat kering benihnya.

2) Indikator fisiologis

a. Viabilitas benih, yaitu mengukur daya kecambah benih yang dipanen pada pada umur 14 hsbm, umur 17 hsbm, umur 20 hsbm, umur 23 hsbm, umur 26 hsbm, dan umur 29 hsbm. Daya kecambah benih diukur dengan cara mengecambahkan 100 butir benih pada germinator dengan metode uji kertas digulung dalam plastik (UKDdp) dengan 3 kali ulangan. Pengamatan terhadap jumlah kecambah normal dilakukan pada hari ke-5 dan ke-7. b. Vigor benih, yaitu dengan mengukur keserempakan berkecambah benih yang dipanen pada umur $14 \mathrm{hsbm}$, umur 17 hsbm, umur 20 hsbm, umur 23 hsbm, umur 26 hsbm, dan umur 29 hsbm. Keserempakan berkecambah benih diukur dengan cara mengecambahkan 100 butir benih pada germinator dan mencatat jumlah kecambah normal pada pengamatan hari ke-5. Pengukuran keserempakan berkecambah benih diulang sebanyak 3 kali.

3) Indikator morfologis, yaitu dengan mencatat perubahan warna polong dan warna benih setiap kali panen.

Data hasil pengamatan dianalisis sidik ragam sesuai rancangan yang digunakan, dan dilanjutkan dengan uji BNT pada taraf $5 \%$. 


\section{HASIL DAN PEMBAHASAN}

Perkembangan karakter polong dan biji tanaman kacang panjang (Gambar 1) dapat digunakan untuk menentukan waktu panen polong untuk menghasilkan benih bermutu. Selama perkembangan, polong dan biji mengalamai perubahan secara morfologi baik ukuran maupun warna, sejak umur 14 hsbm sampai dengan umur 29 hsbm. Demikian juga perubahan ukuran bijinya sejalan dengan perubahan ukuran polong dan pada saat polong mencapai ukuran maksimum (umur 23 hsbm) biji telah berubah warna dari warna hijau muda menjadi warna hijau keabu-abuan. Selanjutnya warna polong berubah pada umur 26 hsbm yaitu dari warna hijau kekuning-kuningan menjadi kuning, dan pada saat itu biji seluruhnya sudah berubah menjadi berwarna abu-abu. Hal ini menunjukkan bahwa kemasakan biji sejalan dengan kemasakan buah (polong). Perubahan warna pada polong maupun biji dapat dipakai sebagai penanda tingkat kemasakan polong maupun biji. Perubahan warna polong diikuti oleh perubahan warna biji (Gambar 1). Perubahan warna polong sudah menjadi kuning (umur 26 hsbm) dapat ditetapkan sebagai tanda biji sudah masak fisiologis dan waktu panen yang tepat. Suharsi et al. (2015) menggunakan perubahan warna kulit buah untuk menentukan tingkat kemasakan biji pada tanaman cabai. Takac et al. (2015) menyatakan bahwa pad tanaman terung, tingkat kematangan benih dapat dicirikan dari tingkat kematangan buahnya. Proses pemasakan merupakan perubahan morfologi dan fisiologi yang terjadi dalam bakal buah dan bakal benih sejak pembuahan sampai buah masak fisiologis. Mutu benih meningkat secara bertahan selama proses pemasakan dan umumnya menjadi lebih tinggi bila akumulasi bahan kering tercapai maksimum (Olasoji et al., 2012). Pada tanaman tembakau, penampilan buah secara fisik dipakai sebagai indikator dari kemasakan dan mutu benih (Andrade et al., 2018). Untuk sebagian besar spesies tumbuhan, titik panen yang ideal bergantung pada kematangan fisiologis benih. Pada saat itu pemindahan bahan kering dari tumbuhan ke benih berhenti atau benih telah memiliki bahan kering maksimum (Lima et al., 2012). 


\section{IDA AYU MAYUN et al. Penentuan Waktu Panen untuk Produksi Benih...}

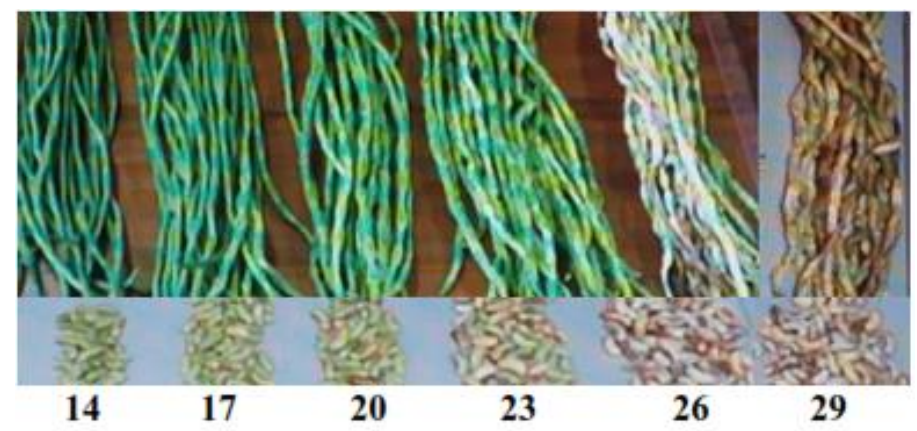

Tampilan visual polong ( (hari setelah bunga mekar)

Gambar 1. Perkembangan Karakter Polong dan Biji Tanaman Kacang Panjang

Tabel 1 menunjukkan bahwa saat polong mencapai umur 26 hsbm, perkembangan berat segar dan berat kering oven biji didapatkan dengan nilai tertinggi berturut-turut sebesar 9,48 g dan 7,56 g. Berdasarkan perkembangan berat biji, pada umur 26 hsbm dapat ditetapkan sebagai umur panen polong yang tepat untuk mendapatkan benih bermutu. Pada saat polong berumur $26 \mathrm{hsbm}$ tersebut benih diduga telah mencapai masak fisiologis sehingga benih memiliki cadangan makanan maksimum dengan kadar air biji cukup rendah (sebesar 20,25\%). Bareke
(2018) menyatakan bahwa benih yang telah masak fisiologis mempunyai cadangan makanan sempurna (maksimum) sehingga dapat menunjang pertumbuhan kecambah. Pada saat polong berumur $29 \mathrm{hsbm}$ berat segar dan berat kering benih mengalami penurunan. Hal ini berarti bahwa polong umur 29 hsbm merupakan waktu panen lewat masak fisiologis. Sedangkan pada saat polong berumur $23 \mathrm{hsbm}$ berat benih belum mencapai maksimum (Tabel 1) berarti polong dan biji belum mencapai masak fisiologis. 
Tabel 1. Pengaruh umur panen polong terhadap kadar air, berat segar, berat kering oven, daya kecambah, dan keserempakan tumbuh benih kacang panjang

\begin{tabular}{|c|c|c|c|c|c|c|c|}
\hline \multirow[t]{2}{*}{ Variabel } & \multicolumn{6}{|c|}{ Umur panen Polong (hari setelah bunga mekar) } & \multirow{2}{*}{$\begin{array}{l}\text { BNT } \\
5 \%\end{array}$} \\
\hline & 14 & 17 & 20 & 23 & 26 & 29 & \\
\hline Kadar air biji (\%) & $45,64 \mathrm{a}$ & $37.80 \mathrm{~b}$ & $29,73 \mathrm{c}$ & $23,81 \mathrm{~d}$ & $20,25 \mathrm{e}$ & $23,82 \mathrm{~d}$ & 3,75 \\
\hline Berat segar biji (g) & $6,88 \mathrm{c}$ & $7,29 \mathrm{bc}$ & $8,61 \mathrm{abc}$ & $9,03 \mathrm{ab}$ & 9,48 a & $9,15 \mathrm{abc}$ & 2,56 \\
\hline $\begin{array}{l}\text { Berat kering oven biji } \\
(\mathrm{g})\end{array}$ & $3,74 \mathrm{c}$ & $5,29 \mathrm{~b}$ & $6,05 \mathrm{~b}$ & 6,88 a & 7,56 a & 6,97 a & 1,27 \\
\hline $\begin{array}{l}\text { Daya kecambah biji } \\
(\%)\end{array}$ & $75,57 \mathrm{~d}$ & $87,26 \mathrm{c}$ & $100,00 \mathrm{a}$ & $100,00 \mathrm{a}$ & $100,00 \mathrm{a}$ & $93,22 \mathrm{~b}$ & 3,12 \\
\hline $\begin{array}{l}\text { Keserempakan tumbuh } \\
\text { biji }(\%)\end{array}$ & $25,34 \mathrm{f}$ & $35,76 \mathrm{e}$ & $58,98 \mathrm{~d}$ & $75,45 \mathrm{c}$ & 88,78 a & $80,11 \mathrm{~b}$ & 8,98 \\
\hline
\end{tabular}

Keterangan: Nilai rata-rata yang diikuti oleh huruf yang sama pada masing-masing variabel berarti berbeda tidak nyata berdasarkan uji BNT 5\%.

Data pada Tabel 1 juga menunjukkan bahwa saat polong berumur $26 \mathrm{hsbm}$, karakter variabel mutu benih didapatkan dengan nilai rata-rata tertinggi berturutturut $100 \%$ (daya kecambah), dan $88,78 \%$ (keserempakan tumbuh benih). Walaupun daya kecambah benih pada umur polong 20 hsbm dan 23 hsbm sudah mencapai 100\%, tetapi belum didukung oleh berat kering biji yang maksimum sehingga nilai daya kecambah tersebut belum bisa dipakai sebagai dasar penentuan waktu panen polong. Selanjutnya saat polong berumur 29 hsbm nilai rata-rata variabel daya kecambah dan keserempakan tumbuh sudah mulai menurun.

Saat masak fisiologis benih memiliki cadangan makanan yang cukup untuk mendukung proses perkecambahan (Santoso et al., 2012). Penambahan umur polong dari umur $26 \mathrm{hsbm}$ sampai dengan umur $29 \mathrm{hsbm}$ menyebabkan nilai rata-rata daya kecambah dan keserempakan tumbuh lebih rendah dibandingkan dengan saat polong berumur $26 \mathrm{hsbm}$. Hal ini disebabkan karena benih mengalami deraan cuaca lapang selama penundaan waktu panen. Deraan cuaca lapang dapat menyebabkan benih mengalami kemunduran mutu (deteriorasi) (Jyoti \& Malik, 2013).

\section{SIMPULAN}

Berdasarkan pembahasan yang telah diuraikan di atas maka dapat disimpulkan waktu panen polong yang terbaik untuk 


\section{IDA AYU MAYUN et al. Penentuan Waktu Panen untuk Produksi Benih...}

menghasilkan benih bermutu tanaman kacang panjang adalah umur 26 hari setelah bunga mekar, dengan ciri-ciri visual polong telah berubah warna dari berwarna hijau menjadi berwarna kuning. Benih tanaman kacang panjang pada panen polong umur 26 hari setelah bunga mekar memiliki berat segar benih $(9,48 \mathrm{~g})$ dan berat kering oven benih $(7,56 \mathrm{~g})$ tertinggi, dan kadar air benih $(20,25 \%)$ terendah. Daya kecambah dan keserempakan tumbuh benih tanaman kacang panjang dengan nilai rata-rata tertinggi (berturut-turut $100 \%$ dan $88,78 \%$ ) juga didapatkan pada saat panen polong umur 26 hari setelah bunga mekar.

\section{DAFTAR PUSTAKA}

Andrade, D. B., Silva, H. P., Carvalho, M. L. M., Oliveira, A. S., Santos, H. O., \& Neta, I. C. S. (2018). Research Article Morphological, physiological, and biochemical indicators of quality in tobacco fruits and seeds. Genetics and Molecular Research, 17(4). https://doi.org/10.4238/gmr18058

Bareke, T. (2018). Biology of seed development and germination physiology. Advances in Plants \& Agriculture Research, 8(4). https://doi.org/10.15406/apar.2018.08 .00335

Calderini, D. F., Abeledo, L. G., \& Slafer, G. A. (2000). Physiological Maturity in Wheat Based on Kernel Water and Dry Matter. Agronomy Journal, 92(5), 895-901. https://doi.org/10.2134/agronj2000.92 $5895 \mathrm{x}$
Jyoti, \& Malik, C. P. (2013). Seed Deterioration: A Review. International Journal of Life Sciences Biotechnology and Pharma Research, 2(3), 376-385.

Lima, C. R. de, Bruno, R. de L. A., Silva, K. da R. G. da, Pacheco, M. V., Alves, E. U., \& Andrade, A. P. de. (2012). Physiological maturity of fruits and seeds of Poincianella pyramidalis (Tul.) L.P. Queiroz. Revista Brasileira de Sementes, 34(2), 231-240.

https://doi.org/10.1590/S0101-

31222012000200007

Nleya, T., \& Kleinjan, J. (2019). Corn Growth and Development. IGrow Corn: Best Management Practices, $1-10$.

Olasoji, O. J., Owolade, O. F., Badmus, R. A., Olosunde, A. A., \& Okoh, O. J. (2012). Variation in germination and seed longevity of kenaf (Hibiscus canabinus) as affected by different maturity and harvesting stages. Journal of Stored Products and Postharvest Research, 3(12), 167171. https://doi.org/10.5897/JSPPR12.016 Sanoto, A., Rasyad, A., \& Zuhry, E. (2017). PolaPerkembanganBiji dan Perubahan Mutu Benih Berbagai Kultivar Sorgum(Shorgum bicolor L.)". JOM Faperta, 4(1), 1-12.

Santos, R. F. dos, Gomes-Junior, F. G., \& Marcos-Filho, J. (2020). Morphological and physiological changes during maturation of okra seeds evaluated through image analysis. Scientia Agricola, 77(3). https://doi.org/10.1590/1678-992x2018-0297

Santoso, B. B., Budianto, A., \& Aryana, I. D. P. M. (2012). Seed viability of Jatropha curcas in different fruit maturity stages after storage. 
Agrotrop : Journal on Agriculture Science, 11 (1): 21 - 29 (2021)

Nusantara Bioscience, 4(3). https://doi.org/10.13057/nusbiosci/n0 40305

Suharsi, T. K., Syukur, M., \& Wijaya, A. R. (2015). Karakterisasi Buah dan Penentuan Saat Masak Fisiologi Benih Beberapa Genotipe Cabai (Capsicum annuum L.). Jurnal Agronomi Indonesia (Indonesian Journal of Agronomy), 43(3), 207212.

https://doi.org/10.24831/jai.v43i3.112 46

Takac, A., Popovic, V., Glogovac, S., Dokic, V., \& Kovac, D. (2015). Effects of fruit maturity stages and seed extraction time on the seed quality of eggplant (Solanum melongena L.). Ratarstvo $i$ Povrtarstvo, 52(1), 7-13. https://doi.org/10.5937/ratpov51-7201

Vera Cruz, M. S. F., Rocha, M. E. L., Ristau, A. C. P., Coutinho, P. W. R., Malavasi, M. M., Malavasi, U. C., Braz, H., Klein, D. R., Vitto, D. C., \& Ebeling, N. (2018). Hovenia dulcis T. Fruit Colorimetry for Determination of Physiological Maturity of Seeds. Journal of Agricultural Science, 10(1), 293-301. https://doi.org/10.5539/jas.v10n1p293 